\title{
JURNAL
}

TEKNOLOGI INFORMASI

\section{Perencanaan Strategis Sistem Informasi Menggunakan Metode Ward And Peppard Studi Kasus CV XYZ}

\author{
David Setya Wardhana, Andeka Rocky Tanaamah \\ Fakultas Teknologi Informasi, Universitas Kristen Satya Wacana \\ Salatiga, Indonesia \\ J1. Dr. O. Notohamidjojo Salatiga \\ Email :682015010@student.uksw.edu, atanaamah@uksw.edu
}

\begin{abstract}
Global competition requires companies to move dynamically to the flow of change, one of the things that can be done is to use information systems. CV XYZ already has an information system but there are still some parts that have not implemented the information system. Retrieval of data in this study using interview and observation methods to determine the business environment and corporate information system environment. The method used in this study is Ward and Peppard with SWOT analysis, Value Chain analysis, Five Forces Porter, and Mc Farlan's Strategic Grid. This research generates strategic recommendations, provides internal environmental analysis, external company information systems and proposed information systems namely HRD information systems, After Service information systems, Supplier information systems, Customer service information systems, Administrative information systems, and Promotional information systems, which are priorities in accordance with Mc Farlan's Strategic Grid mapping, and can be applied by the company within the next 3 (three) years.
\end{abstract}

Keywords: Five Forces Porter, Mc Farlan's Strategic Grid, SWOT, Value Chain, Ward and Peppard

\begin{abstract}
Abstrak
Persaingan global menuntut perusahaan untuk bergerak dinamis mengikuti arus perubahan, salah satu hal yang dapat dilakukan yaitu menggunakan sistem informasi. CV XYZ sudah memiliki sistem informasi namun masih ada beberapa bagian yang belum menerapkan sistem informasi. Pengambilan data pada penelitian ini menggunakan metode wawancara dan observasi untuk mengetahui lingkungan bisnis dan lingkungan sistem informasi perusahan. Metode yang digunakan pada penelitian ini adalah Ward and Peppard dengan analisis SWOT, analisis Value Chain, Five Forces Porter, dan Mc Farlan's Strategic Grid. Penelitian ini menghasilkan rekomendasi strategi, memberikan analisis lingkungan internal, eksternal sistem informasi perusahaan dan usulan sistem informasi yaitu Sistem informasi HRD, Sistem informasi After Service, Sistem informasi Supplier, Sistem informasi customer services, Sistem informasi administrasi, dan Sistem informasi promosi, yang menjadi prioritas sesuai dengan pemetaan Mc Farlan's Strategic Grid, dan dapat diterapkan perusahaan dalam kurun waktu 3 (tiga) tahun mendatang.
\end{abstract}

Kata kunci: Five Forces Porter, Mc Farlan's Strategic Grid, SWOT, Value Chain, Ward and Peppard 
AITI: Jurnal Teknologi Informasi

Volume 16 No. 1 Februari 2019, 18-30

\section{Pendahuluan}

Perencanaan Strategis SI/TI digunakan untuk menyelaraskan antara kebutuhan strategi bisnis dan strategi SI/TI untuk mendapatkan nilai tambah dari suatu organisasi dari segi keunggulan kompetitif [1]. Di dalam jurnalnya Erly Farida Elisabeth menyebutkan bahwa "untuk menggunakan sistem informasi, tidak melihat dari besar kecilnya suatu perusahaan. Dengan adanya peranan sistem informasi, dapat membuat segala kegiatan operasional dalam perusahaan menjadi lebih mudah dan cepat. Perkembangan sistem dan teknologi informasi yang sangat cepat sekarang ini, dapat membuat dunia bisnis dan tingkat persaingan akan semakin meningkat, sehingga menjadikan sistem dan teknologi informasi (SI/TI) tersebut memegang peranan penting pada perusahaan dalam mencapai tujuan[2]”.

SI/TI yang berada di CV XYZ sudah mencakup seluruh area pabrik, namun belum digunakan secara maksimal yang menyebabkan beberapa kegiatan pengerjaan masih manual contohnya yaitu kontrak kerja karyawan, perusahaan memiliki banyak karyawan tidak tetap, namun kontrak kerja yang masih manual menghambat kerja karyawan itu sendiri karena proses tersebut membutuhkan waktu yang cukup lama, maka dari itu dengan menerapkan perancanaan strategis Sistem Informasi yang matang dan tepat sasaran diharapkan mampu mengurangi kendala yang ada sehingga dapat mempermudah pekerjaan membuat proses bisnis lebih efektif dan efisien.

Perencanaan strategis penting karena tanpa adanya perencanaan strategis sistem informasi, perusahaan akan kesulitan dalam menyelaraskan visi misi dengan strategi SI. Berdasarkan latar belakang yang ada maka yang menjadi rumusan masalah dalam penelitian ini adalah bagaimana menyusun perencanaan strategis sistem informasi menggunakan metode Ward And Peppard. metode - metode yang digunakan dalam penelitian ini adalah SWOT untuk mengetahui kekuatan, kelemahan, peluang dan ancaman perusahaan, Value chain untuk menggambarkan aktivitas proses bisnis utama dan proses bisnis pendukung dari perusahaan. Hasil analisis ini kemudian akan digunakan untuk mengidentifikasi kebutuhan sistem informasi di perusahaan, Five Forces Porter untuk mengetahui 5 kekuatan eksternal yang menjadi ancaman Perusahaan, MC Farlan Grid untuk memetakan aplikasi atau sistem kedalam 4 bagian yaitu strategic grid, high potential, key operational, support.

Penelitian ini menggunakan five forces porter karena perusahaan bergerak di bidang manufaktur sehingga five forces porter lebih tepat karena didalamnya membahas tentang pesaing bisnis sejenis, ancaman pendatang baru, daya tawar pelanggan, daya tawar pemasok, dan ancaman produk pengganti, hal tersebut sangat berhubungan dengan perusahaan yang bergerak dalam bidang manufaktur. Penelitian ini tidak menyebutkan nama objek penelitian karena permintaan perusahaan terkait persaingan bisnis. 


\section{Kajian Pustaka}

Penelitian yang membahas perencanaan strategis sistem informasi menggunakan metode Ward and Peppard sudah cukup banyak dilakukan dalam beberapa sektor. Penelitian yang pertama berjudul "Perencanaan Strategis Sistem Informasi Menggunakan Metode Ward And Peppard" (Studi Kasus: Pada STMIK Parna Raya Manado). Menggunakan tools SWOT, value chain, CSF, Porter Five Forces dan akhirnya ditampilkan dalam portofolio system informasi MC Farlan mengungkapan bahwa hasil dari perencanaan strategis SI/TI di STMIK dapat mendukung aktivitas bisnis yang dilakukan sehingga selaras dengan visi, misi, dan tujuan yang ditetapkan diawal [3].

Penelitian yang kedua berjudul "Perencanaan Strategis Sistem Informasi Untuk Meningkatkan Pelayanan Menggunakan Metode Ward And Peppard" ( Studi Kasus : PT Pos Indonesia Cilegon - Banten). menggunakan 2 pendekatan, yang pertama metodologi pemaduan strategis dan yang kedua metodologi dampak kompetitif, memberikan beberapa rekomendasi kepada PT Pos untuk membuat beberapa aplikasi agar pelayanan yang di lakukan oleh PT Pos Indonesia bisa berjalan lebih baik, aplikasi yang di rekomendasikan adalah Aplikasi sistem informasi coorporate, sistem informasi pembelian, SMS Gateway, Sistem informasi produk pos dan lain-lain, mengungkapkan bahwa dengan diadakan tambahan aplikasi maka dapat memperbaiki pelayanan dan menambah keuntungan perusahaan [4].

Penelitian yang ketiga berjudul "Perencanaan Strategis Sistem Informasi / Teknologi Informasi Pada Perusahaan Manufaktur Menggunakan Metodologi Ward and Peppard" (Studi Kasus: PT. Cerah Indah Grafika, Semarang). menggunakan 3 tahap penelitian, Dari hasil penelitian yang dilakukan menggambarkan bahwa sistem informasi yang dimiliki oleh PT Cerah Grafika belum dapat mendukung proses bisnis perusahaan secara keseluruhan. Hasil dari penyusunan perencanaan strategi sistem informasi khususnya pada aplikasi yang digunakan dalam proses bisnis ini adalah untuk Memberikan panduan bagi manajemen untuk meningkatkan produktivitas perusahaan di bidang percetakan[5].

Hubungan penelitian ini dengan tiga penelitian sebelumnya adalah membuat suatu perencanaan strategis sistem informasi dengan metode Ward and Peppard yang dapat mendukung aktivitas perusahaan. Penelitian ini membuat rencana strategis sistem informasi di CV XYZ dengan menganalisis sistem informasi yang ada untuk membuat proses kerja yang ada semakin baik, efektif dan efisien.

\section{Perencanaan Strategis}

Perencanaan strategis adalah suatu rencana jangka panjang yang bersifat menyeluruh, memberikan rumusan terhadap suatu perusahaan/organisasi mengenai 
AITI: Jurnal Teknologi Informasi

arahan dan bagaimana sumber daya dialokasikan untuk mencapai tujuan selama jangka waktu tertentu dalam berbagai kemungkinan keadaan lingkungan[6].

Perencanaan strategis adalah proses pemilihan tujuan organisasi, penentuan strategi, program-program strategi, dan penetapan metode - metode yang diperlukan untuk menjamin bahwa strategi dan kebijakan telah diimplementasikan[7].

\section{Perencanaan Strategis Sistem Informasi}

Perencanaan strategis sistem informasi merupakan proses identifikasi portofolio aplikasi SI berbasis komputer yang mendukung suatu organisasi dalam pelaksanaan rencana bisnis dan merealisasikan tujuan bisnisnya. Perencanaan strategis SI/TI mempelajari pengaruh SI/TI terhadap kinerja bisnis dan kontribusi bagi organisasi dalam memilih langkah-langkah strategis. Selain itu, perencanaan strategis SI/TI juga menjelaskan berbagai alat, teknik, dan kerangka kerja bagi manajemen untuk menyelaraskan strategi SI/TI dengan strategi bisnis, bahkan mencari kesempatan baru melalui penerapan teknologi yang inovatif [1].

Faktor terpenting dalam proses perencanaan strategis SI/TI adalah penggunaan metodologi, dengan tujuan bahwa penggunaan metodologi dalam perencanaan strategis SI/TI meminimalkan resiko kegagalan, memastikan keterlibatan semua pihak yang berkepentingan, meminimalkan ketergantungan individu, serta lebih menekankan kepada proses dan sasaran yang ditentukan [8]

Strategi sistem informasi dan strategi teknologi informasi yang dikembangkan harus dapat menunjang strategi bisnis perusahaan yang bersangkutan. Dengan demikian, akan dihasilkan sebuah perencanaan strategis sistem informasi yang komprehensif sehingga dapat menjamin keuntungan yang akan diperoleh perusahaan atas investasi teknologi informasi yang dikeluarkan [8].

\section{Metode Ward and Peppard}

Metode Ward and Peppard adalah metode perencanaan strategis sistem informasi yang dikembangkan oleh Ward and Peppard. Metode ini diharapkan menghasilkan portofolio aplikasi untuk suatu perusahaan. Gambar 1 merupakan skema perencanaan strategis sistem informasi menurut Ward and Peppard.

Tahapan perencanaan strategi SI/TI ini terdiri dari tahapan masukan dan tahapan keluaran[9]. Tahapan masukan terdiri dari:

1. Analisis lingkungan bisnis internal, yang mencakup aspek-aspek strategi bisnis saat ini, seperti visi, misi dan tujuan organisasi, aktivitas dan proses bisnis organisasi, sumber daya yang dimiliki.

2. Analisis lingkungan bisnis eksternal, yang mencakup aspek - aspek persaingan dengan perusahaan atau organisasi lainnya. Lingkungan bisnis eksternal dapat memacu perusahaan untuk maju dan bersaing namun juga 
dapat memberikan hambatan bahkan ancaman terhadap kelangsungan hidup organisasi.

3. Analisis lingkungan SI/TI internal, yang mencakup kondisi SI/TI organisasi dari perspektif bisnis saat ini, mengetahui software dan hardware yang digunakan.

4. Analisis lingkungan SI/TI eksternal, yang mencakup tren teknologi dan peluang pemanfaatannya, serta penggunaan SI/TI oleh kompetitor. Analisis ini digunakan untuk mendapatkan pemahaman terhadap perkembangan SI/TI diluar organisasi yang dapat memberikan dampak terhadap organisasi atau perusahaan.

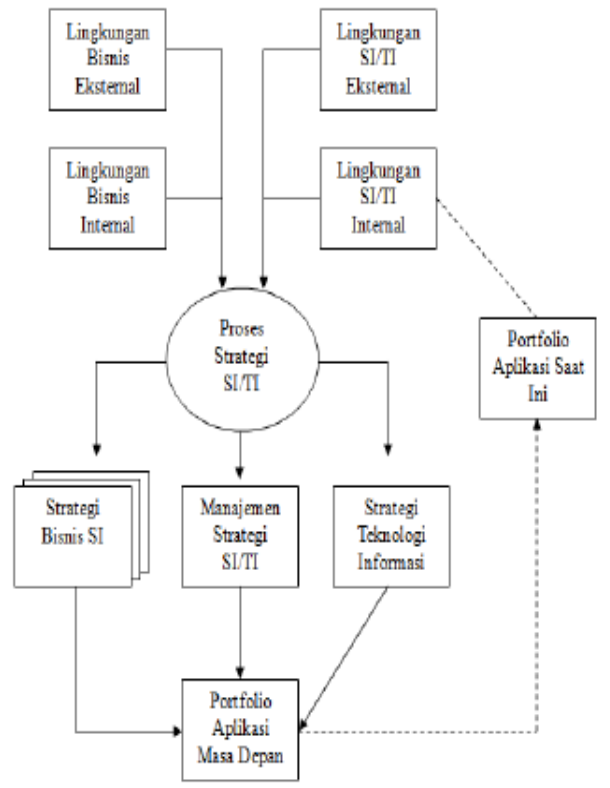

Gambar 1 Skema Perencanaan Strategis Ward and Peppard

Sedangkan tahapan keluaran pada penelitian ini yang dihasilkan oleh metode ward and peppard adalah suatu dokumen perencanaan strategis sistem informasi yang berupa :

1. Strategi bisnis Sistem informasi

2. Strategi manajemen

3. Strategi sistem informasi/ teknologi informasi.

Selanjutnya dari strategi - strategi yang ada akan dibuat portofolio atau usulan - usulan aplikasi untuk masa yang akan datang.

\section{Metode Penelitian}

Metodologi penelitian yang akan dilakukan di CV XYZ menggunakan pendekatan kualitatif. Pendekatan ini digunakan untuk mendeskripsikan data dan fakta yang terjadi di lapangan. "pendekatan kualitatif ialah pendekatan yang di dalam usulan penelitian, proses, hipotesis, turun ke lapangan, analisis data dan kesimpulan data sampai dengan penulisannya mempergunakan aspek-aspek 
AITI: Jurnal Teknologi Informasi

kecenderungan, non perhitungan numerik, situasional deskriptif, dan interview mendalam[10]". Penelitian ini menggunakan beberapa tahap yang saling berkaitan.

Tahapan pertama melakukan wawancara dan observasi dengan Supervisor IT di CV XYZ. Pengambilan data akan dilakukan selama 2 bulan di bagian HR dan IT CV XYZ, mengambil data tentang penerapan penggunaan SI/TI, visi misi, dan bagian - bagian dalam perusahaan. Tahapan kedua melakukan analisa proses bisnis internal perusahaan seperti kekuatan, kelemahan, ancaman, peluang serta aktivitas utama dan pendukung, menganalisa persaingan bisnis dengan perusahaan sejenis pada CV XYZ. Penelitian akan menggunakan metode SWOT analisis, Value Chain, five Forces porter, MC Farlan Strategic Grid. Alasan diambilnya data tersebut untuk mengambil langkah pertama dalam merancang metode Ward and Peppard dan untuk mengetahui masalah-masalah yang ada, sesuai dengan metode Ward and Peppard sehingga dapat memberikan usulan-usulan aplikasi agar proses bisnis perusahaan berjalan lebih baik lagi. Selanjutnya melakukan analisa proses bisnis dan SI/TI, untuk mengetahui pemanfaatan SI/TI Perusahaan. Tahapan ketiga menyusun strategi SI/TI, Strategi bisnis, Strategi Manajemen berdasarkan analisis yang di dapatkan dalam tahapan sebelumnya. Tahapan keempat menyusun usulan aplikasi untuk mengetahui prioritas aplikasi yang akan diterapkan. Tahapan kelima memetakan usulan aplikasi untuk diterapkan dalam tiga tahun ke depan.

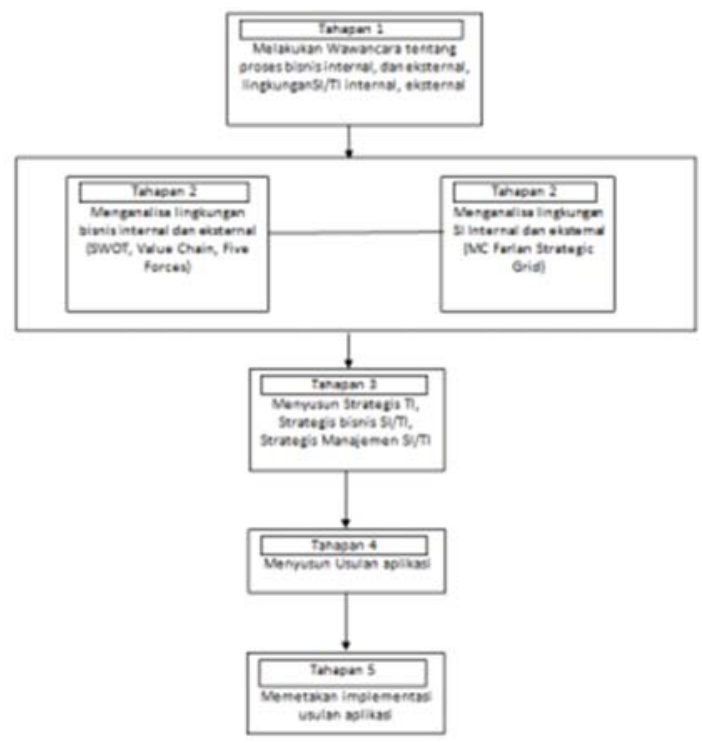

Gambar 2 Tahapan Penelitian

\section{Hasil dan Pembahasan}

Berdasarkan hasil wawancara dan observasi yang sudah dilakukan, CV XYZ belum memiliki perencanaan strategis sistem informasi, oleh karena itu perlu dirumuskan suatu perencanaan strategis sistem informasi guna meningkatkan keunggulan kompetitif perusahaan dan meningkatkan efisiensi kerja. Perencanan strategis dimulai dari menganalis lingkungan internal dan eksternal perusahaan, 
kemudian analisa lingkungan SI/TI perusahaan, menentukan strategi hingga melakukan pemetaan usulan sistem informasi. Pertama yang dilakukan adalah analisa lingkungan bisnis internal/eksternal.

\section{A. Analisis Lingkungan Bisnis Internal/Eksternal SWOT}

Tahap pertama penelitian ini menggunakan SWOT, CV XYZ memilki beberapa SWOT yang dapat dianalis. SWOT digunakan untuk mengetahui kekuatan, kelemahan, peluang dan ancaman dengan melihat lingkungan internal dan eksternal dari CV XYZ. Berikut adalah analisis beserta strategi SWOT :

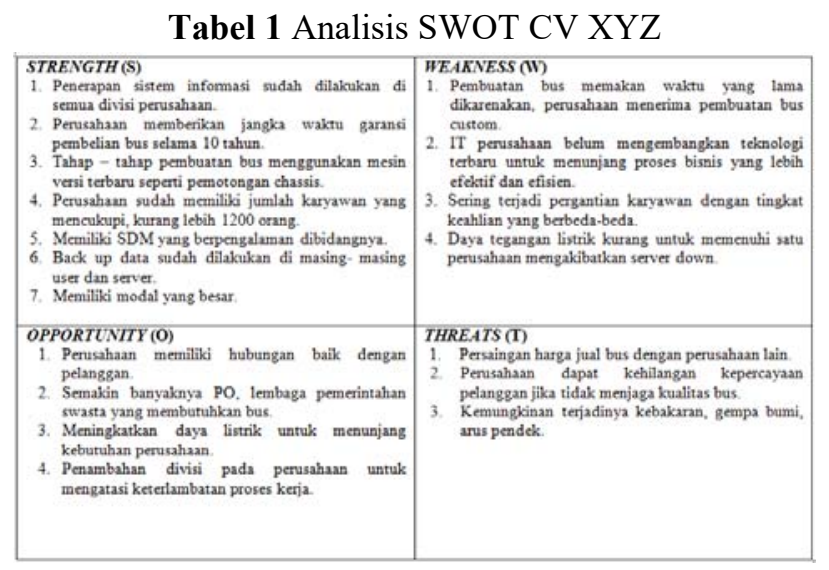

Dari hasil analisis SWOT yang dilakukan, maka selanjutnya dapat dirumuskan strategi yang dapat diterapkan oleh perusahaan. Berikut beberapa strategi yang dihasilkan:

Strategi strength and opportunity (SO) yaitu perusahaan dapat memperbanyak promosi sehingga meningkatkan jumlah order dan meningkatkan Standar pembuatan kualitas bus dengan adanya SDM yang berpengalaman dibidangnya, selanjutnya perusahaan berpotensi untuk memperluas pasar dengan semakin banyaknya pihak yang memerlukan bus. Strategi weakness and opportunity (WO), mempercepat waktu produksi tanpa adanya kecacatan sehingga hubungan baik dengan pelanggan semakin terjaga dan melakukan Training kepada karyawan untuk menghasilkan produk dengan kualitas yang sama. Perusahaan dapat melakukan penambahan divisi sehingga dapat mempercepat waktu produksi dan meningkatkan daya listrik untuk menghindari terjadinya server down akibat sering terjadinya turun listrik. Strategi strength and threats (ST), Melakukan kunjungan ke customer secara rutin, memastikan kondisi bus yang masih memiliki garansi dapat digunakan sebagaimana mestinya sehingga komunikasi dengan customer tetap berjalan baik. Strategi weakness and threats (WT), perusahaan dapat menekan biaya produksi dengan memanfaatkan teknologi, sehingga harga produk dapat bersaing dengan perusahaan lain, menjaga serta meningkatkan kualitas bus dengan cara mengganti karyawan dengan tingkat keahlian yang sama atau dengan keahlian yang lebih baik. 
AITI: Jurnal Teknologi Informasi

\section{Analisa Five Forces Porter}

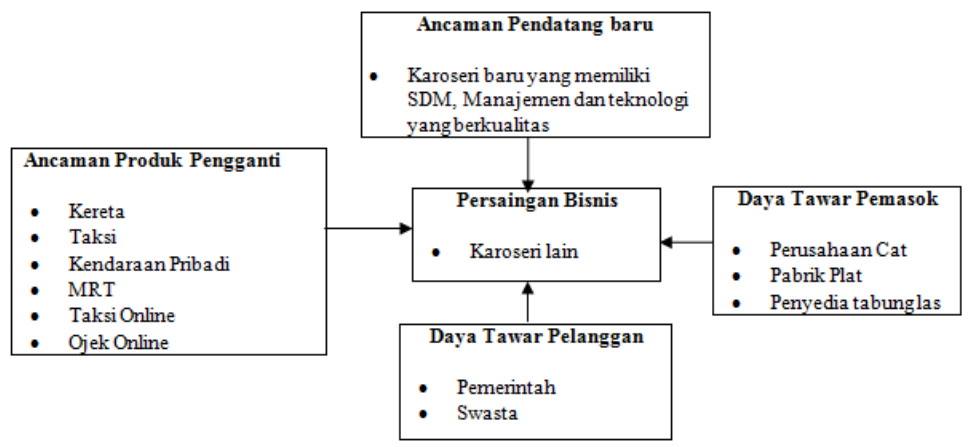

Gambar 3 Pemenataan Five Forces Porter CV XYZ

Analisis selanjutnya menggunakan metode Five Forces. Metode Five Forces digunakan untuk menganalisa lingkungan eksternal dari perusahaan. Pertama pesaing bisnis sejenis, perusahaan memiliki strategi untuk dapat bersaing dengan perusahaan sejenis lain yaitu menggunakan teknologi mesin yang tebaru sehingga kualitas produk yang dihasilkan lebih baik lagi. selain itu dapat mempermudah pegawai dalam melakukan pekerjaannya. Kedua ancaman pendatang baru dikuatirkan adanya pendatang baru yang memiliki manajemen dan alat yang lebih baik dari perusahaan akan membuat pelanggan akan berpindah, karena dengan manajemen dan alat yang lebih baik akan membuat jangka waktu produksi lebih singkat, dan inilah yang membuat pelanggan - pelanggan lebih tertarik dengan pendatang baru tersebut karena pada dasarnya customer suka terhadap karoseri yang cepat. Dalam hal ini XYZ harus menyadari untuk membuat manajeman yang disiplin, dan selalu memperbaharui alat produksi sehingga jangka waktu produksi lebih singkat.

Ketiga daya tawar pelanggan, sesuai dengan analisis yang dilakukan, pelanggan memiliki banyak keleluasaan untuk memilih karoseri yang ada berdasarkan kualitas produk, harga, waktu pengerjaan. Jadi perusahaan harus menetapkan harga yang tepat, selalu menjaga kualitas produksi, selain itu harus menjaga hubungan baik dengan pelanggan. Keempat daya tawar pemasok, XYZ memiliki banyak pemasok diantaranya Sasdoor, USCI dll. Perusahaan memiliki kewenangan dalam memilih supplier sesuai dengan standar yang sudah ditentukan. Hal ini menguntungan perusahaan karena dengan adanya banyak supplier dalam satu produk, perusahaan dapat memilih supplier sesuai dengan kriteria yang sudah ditentukan. Kelima ancaman produk pengganti, bus dapat digantikan oleh kereta, taksi, MRT, dan kendaraaan pribadi, taksi online, dan ojek online. Oleh karena itu perusahaan harus tetap menjaga kualitas produk, membuat pelanggan puas sehingga karoseri bus tetap eksis di Indonesia. 


\section{Analisis Value Chain Activity}

Analisis ini digunakan untuk mengetahui aktivitas utama dan aktivitas pendukung lingkungan bisnis internal perusahaan, dengan melihat proses bisnis maka dapat diketahui kebutuhan aplikasi untuk menunjang aktivitas bisnis utama, sehingga proses bisnis lebih efektif dan efisien. Berikut adalah hasil analisis value chain CV XYZ :

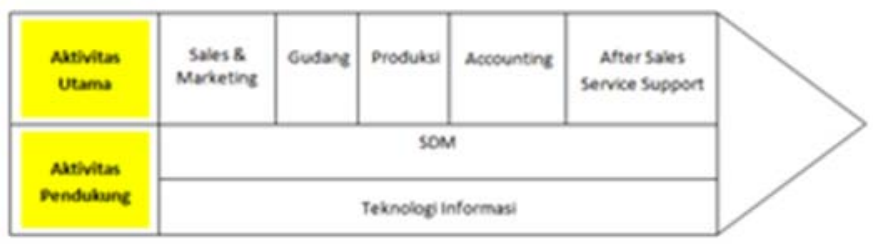

Gambar 4 Diagram Value Chain CV XYZ

Aktivitas utama perusahaan antara lain a). bagian Marketing bertugas untuk memasarkan dan menjelaskan spesifikasi bus ke customer, bagian sales membuat penawaran kepada customer tentang bus dengan spesifikasi beserta harga, setelah customer setuju maka akan di buatkan order didalam sistem. b). Bagian Gudang akan menampung material-material yang sudah disediakan oleh bagian Preparation, bagian Komponen dan Logistik. Bagian preparation dan Komponen menyediakan material yang bisa di buat di pabrik, bagian Logistik menyediakan material yang di beli dari luar. c). Bagian Produksi bertugas membuat bus, terdapat 3 bagian yaitu Body \& Rangka, Dempul \& Cat, Finishing. Pengerjaan ini akan di kontrol oleh PPIC mulai bus dibuat sampai bus jadi. Setelah bus jadi maka akan di cek oleh Quality Control untuk mengetahui kualitas bus apakah sesuai dengan standart. Quality Control tidak hanya mengecek saat bus sudah jadi, tetapi di setiap bagian Produksi terdapat Quality Control d). Bagian Accounting bertugas membuat invoice kepada customer, dan bertanggungjawab menerima pembayaran dari customer. e) Bagian After Sales Service Support bertugas untuk memberikan service setelah bus dikirim ke customer.

Aktivitas Pendukung antara lain a) Bagian SDM Bertugas untuk menyiapkan sumber daya manusia untuk dapat bekerja dengan maksimal dengan cara mengadakan pelatihan kepada karyawan yang ada di perusahaan. b) bagian IT bertugas melakukan support pada seluruh bagian perusahaan yang memiliki kendala dalam bidang IT, mengontrol server yang ada supaya tetap berjalan dengan baik, melakukan Backup data setiap hari, melakukan maintenance terhadap hardware perusahaan.

\section{B. Analisa Lingkungan SI/TI Internal/Eksternal}

Analisa lingkungan SI/TI internal menggunakan Mc Farlan Strategic Grid digunakan untuk melihat kondisi SI/TI di perusahaan, adapun daftar aplikasi yang dimiliki oleh perusahaan adalah SIM XYZ, Power Logic, syteline, SSRS, dan MS Office. Masing - masing SI/TI digunakan oleh beberapa divisi. SIM XYZ 
AITI: Jurnal Teknologi Informasi

digunakan oleh bagian personalia, Quality Control, Marketing, dan PPIC berbentuk dekstop. Power logic digunakan oleh divisi produksi dan akuntansi. Syteline digunakan untuk job order, customer order, job material. SSRS digunakan untuk pelaporan setiap divisi, MS Office digunakan oleh setiap divisi di perusahaan.

Setelah dilakukan analisis, dan mengetahui sistem informasi yang ada di perusahaan, maka dipetakan menggunakan Mc Farlan Grid sebagai berikut:

Tabel 2 Pemetaan SI/TI CV XYZ Berdasarkan MC Farlan Strategic

\begin{tabular}{lc}
\hline \multicolumn{1}{c}{ HIGH POTENTIAL } & STRATEGIC \\
\hline SIM XYZ & \\
Power Logic & MS Office \\
SSRS & \\
\hline \multicolumn{2}{c}{ KEY OPERATIONAL } \\
\hline
\end{tabular}

Analisa lingkungan SI/TI eksternal, melihat tren penggunaan SI/TI saat ini, banyak perusahaan atau organisasi yang sudah menggunakan SI/TI, tidak hanya berbasis desktop, saat ini perusahaan atau organisasi mulai menggunakan SI/TI berbasis mobile. Terdapat banyak manfaat saat perusahaan menggunakan SI/TI diantaranya memudahkan pencarian informasi, memudahkan pengarsipan data, meningkatkan efektivitas dan efisiensi dalam pekerjaan.

\section{Strategis TI}

Melihat kondisi dibagian pabrik yang kurang baik untuk hardware komputer, maka bagian IT perusahaan harus Menempatkan hardware komputer ditempat yang aman, terutama hardware yang ada di pabrik agar hardware terhindar dari benturan dan debu/kotoran. Sehingga hardware yang ada lebih terjaga dan dapat digunakan secara maksimal.

\section{Strategis Bisnis SI/TI}

Berdasarkan analisis dan observasi yang telah dilakukan di perusahaan tentang SI/TI, menghasilkan beberapa rekomendasi untuk perusahaan, sebagai berikut:

1. Membuat sistem informasi khusus HRD untuk menyimpan data karyawan seperti jumlah keluarga, sehingga dapat diketahui tunjangan-tunjangan yang harus diberikan perusahaan

2. Membuat sistem informasi administrasi untuk menyimpan surat serta berkasberkas yang ada.

3. Membuat sistem informasi untuk kontrak karyawan, sehingga proses kontrak kerja lebih cepat dan tidak mengganggu pekerjaan.

4. Mengoptimalkan dan maintenance server secara berkala untuk meminimalisir terjadiya error.

5. Mengoptimalkan serta menambah hardware untuk absensi karyawan. 


\section{E. Strategis Manajemen SI/TI}

Berdasarkan observasi dan wawancara yang sudah dilakukan didalam divisi IT, perusahaan belum memilki divisi auditor untuk IT, dengan adanya auditor dapat memastikan setiap mekanisme IT dapat berjalan sesuai koridor, mengevaluasi insfrastruktur SI/TI. maka dari itu perusahaan dapat mengadakan divisi auditor internal IT untuk melakukan kontrol terhadap hardware, software, serta server. Sehingga kinerja IT perusahaan lebih optimal.

\section{F. Usulan Aplikasi}

Berdasarkan hasil analisis yang diperoleh dari beberapa tahapan diatas yaitu analisis lingkungan bisnis perusahaan baik lingkungan internal maupun eksternal, maka akan menjadi tahapan usulan strategi sistem informasi untuk CV XYZ. Adapun usulan strategi sistem informasi untuk perusahaan ini adalah:

Tabel 3 Usulan Sistem Informasi CV XYZ

\begin{tabular}{lll}
\hline \multicolumn{1}{c}{ Nama Sistem } & \multicolumn{1}{c}{ Pengguna } & \multicolumn{1}{c}{ Jenis Aplikasi } \\
\hline Sistem Informasi HRD & HRD & Desktop \\
Sistem Informasi After Service & After sales service support & Web \\
Sistem Informasi Supplier & Logistik & Web \\
Sistem Informasi customer services & After sales service support & Web \\
Sistem Infromasi admistrasi & Setiap bagian perusahaan & Desktop \\
Sistem informasi promosi & Sales & Web \\
\hline
\end{tabular}

Berdasarkan usulan sistem informasi yang ada maka akan dipetakan kedalam 4 kuadran Mc Farlan Strategic Grid untuk mengetahui prioritas aplikasi yang akan diterapkan oleh perusahaan untuk masa mendatang. Berikut adalah portofolio aplikasi secara keseluruhan CV XYZ masa mendatang.

Tabel 4 Pemetaan Sistem Informasi CV XYZ Mc Farlan Strategic

\begin{tabular}{ll}
\hline \multicolumn{1}{c}{ HIGH POTENTIAL } & \multicolumn{1}{c}{ STRATEGIC } \\
\hline SIM XYZ & SI Promosi \\
& Customer Services \\
Power Logic & SI HRD \\
SSRS & SI After Service \\
SI Administrasi & SI Supplier \\
Styleline & MS Office \\
\hline \multicolumn{1}{c}{ KEY OPERATIONAL } & \multicolumn{1}{c}{ SUPPORT } \\
\hline
\end{tabular}

\section{G. Pemetaan Implementasi Usulan Sistem Informasi}

Pemetaan implementasi aplikasi dibuat berdasarkan sistem informasi yang sudah diusulkan. Implementasi informasi dibuat selama tiga tahun kedepan, mempertimbangkan keuangan dan waktu yang dimiliki perusahaan untuk dapat membuat usulan sistem informasi karena tidak memungkinkan untuk diimplemetasi secara bersamaan. Tabel 5 menujukkan rencana implementasi usulan sistem informasi. 
AITI: Jurnal Teknologi Informasi

Volume 16 No. 1 Februari 2019, 18-30

Tabel 5 Pemetaan Implementasi Usulan SI CV XYZ

\begin{tabular}{llll}
\hline Solusi SI/TI & $\mathbf{2 0 1 9}$ & $\mathbf{2 0 2 0}$ & $\mathbf{2 0 2 1}$ \\
\hline Sistem informasi HRD & & & \\
Sistem informasi administrasi & & & \\
Sistem informasi Supplier & & & \\
Sistem informasi promosi & & \\
Sistem informasi after service & & \\
Sistem informasi customer services & & \\
\hline
\end{tabular}

Penjelasan rencana implementasi pada CV XYZ: pada tahun 2019 perusahaan membuat sistem informasi HRD dan administrasi. Kedua sistem ini dibutuhkan untuk menyimpan berkas-berkas dan menyimpan data karyawan perusahaan untuk membantu proses pekerjaan sehari-hari. Tahun 2020 membuat sistem informasi supplier dibutuhkan untuk komunikasi dengan supplier mengantisipasi terjadinya kehabisan bahan baku yang tidak disediakan oleh perusahaan, sistem informasi ini dibuat untuk memudahkan perusahaan dalam mengontrol bahan baku. Tahun 2021 sistem informasi promosi, sistem informasi after service, dan sistem informasi customer services. Sistem ini dibuat untuk menjalin hubungan dengan konsumen sehingga kepercayaan konsumen terhadap perusahaan dapat meningkat.

\section{Simpulan}

Berdasarkan analisis serta observasi yang sudah dilakukan, menghasilkan kesimpulan bahwa perusahaan sudah memiliki dan menerapkan sistem informasi di setiap bagian perusahaan. sistem yang ada sudah cukup membantu dan mendukung setiap proses pekerjaan di CV XYZ. Namun masih ada beberapa bagian yang belum menerapkan sistem informasi, oleh karena itu penelitian menggunakan metode Ward and Peppard dengan analisis SWOT, Value Chain, Five Forces Porter dan MC Farlan Strategic Grid menghasilkan 6 (enam) usulan prioritas sistem informasi yaitu Sistem informasi HRD, Sistem informasi After Service, Sistem informasi Supplier, Sistem informasi customer services, Sistem informasi administrasi, dan Sistem informasi promosi, memberikan rekomendasi strategi dan analisis lingkungan bisnis, sistem informasi baik secara internal dan eksternal. Sistem Informasi tersebut dapat diterapkan dalam kurun waktu 3 (tiga) tahun.

Perencanaan strategis, dapat membantu perusahaan mencapai visi dan misi yang ada sehingga perusahaan dapat lebih berkembang.

\section{Daftar Pustaka}

[1] A. Wedhasmara, "Langkah-langkah perencanaan strategis sistem informasi dengan menggunakan metode Ward and Peppard," J. Sist. Inf., vol. 1, no. 1, 2009. 
[2] E. Farida Elisabeth, "PERENCANAAN STRATEGIS SISTEM INFORMASI PD. ALOM JAYA (AJ)," vol. 0, 2011.

[3] F. Manoppo, "Perencanaan Strategis Sistem Informasi Menggunakan Metode Ward And Peppard (Studi Kasus: STMIK Parna Raya Manado),” in Prosiding 2nd Seminar Nasional IPTEK Terapan (SENIT) 2017, 2017, vol. 2, pp. 5662.

[4] A. Anharudin, "PERENCANAAN STRATEGIS SISTEM INFORMASI UNTUK MENINGKATKAN PELAYANAN MENGGUNAKAN METODE WARD AND PEPPARD (Studi Kasus: PT Pos Indonesia CilegonBanten)," PROSISKO J. Pengemb. Ris. Dan Obs. Sist. Komput., vol. 2, no. 2, 2015.

[5] A. M. Nanlohy and A. F. Wijaya, "Perencanaan Strategis Sistem Informasi / Teknologi Informasi Pada Perusahaan Manufaktur Menggunakan Metodologi Ward and Peppard: Studi Kasus: PT. Cerah Indah Grafika, Semarang.," 2016.

[6] Y. Septiana, "Perencanaan Strategis Sistem Informasi Dengan Pendekatan Ward and Peppard Model (Studi Kasus: Klinik INTI Garut),” J. Wawasan Ilm., vol. 8, no. 1, 2017.

[7] F. D. Oes, A. R. Tanaamah, and A. F. Wijaya, "Perencanaan Strategis Sistem Informasi Menggunakan Pendekatan Five Forces dan Value Chain Activity pada Pertambakan Budidaya Udang di PT. Asindo Setia Tama.," 2015.

[8] A. Setiawan and B. Ilman, "Perencanaan Strategik Sistem Informasi pada Perusahaan Penerbitan dengan Metode Ward \& Peppard: Studi Kasus pada Penerbit Rekayasa Sains Bandung,” J. Technol. Manag., vol. 11, no. 3, 2012.

[9] J. Ward, P. M. Griffiths, and P. Whitmore, Strategic planning for information systems, vol. 3. Wiley Chichester, 2002.

[10] L. S. Musianto, "Perbedaan pendekatan kuantitatif dengan pendekatan kualitatif dalam metode penelitian," J. Manaj. Dan Kewirausahaan, vol. 4, no. 2, pp. 123-136, 2004. 